\title{
Landscape influence on small scale water temperature variations in a moorland catchment
}

\begin{tabular}{|r|l|}
\hline Journal: & Hydrological Processes \\
\hline Manuscript ID: & HYP-14-0411.R1 \\
\hline Wiley - Manuscript type: & Research Article \\
\hline Date Submitted by the Author: & n/a \\
\hline Keywords: List of Authors: & $\begin{array}{l}\text { Dick, Jonathan; University of Aberdeen, School of Geoscience } \\
\text { Tetzlaff, Doerthe; University of Aberdeen, Northern Rivers Institute, School } \\
\text { of Geosciences } \\
\text { Soulsby, Chris; University of Aberdeen, School of Geosciences }\end{array}$ \\
\hline & \begin{tabular}{l} 
Stream temperature, Riparian zones, Thermal regime, Connectivity, \\
\hline
\end{tabular} \\
\hline
\end{tabular}




\title{
Landscape influence on small scale water temperature variations in a
} moorland catchment

\author{
J. Dick, D. Tetzlaff and C. Soulsby
}

\section{Northern Rivers Institute, School of Geosciences, University of Aberdeen, Scotland, UK,}

AB24 3UF.

\section{Abstract}

We monitored temperatures in stream water, groundwater and riparian wetland surface water over 18 months in a $3.2 \mathrm{~km}^{2}$ moorland catchment in the Scottish Highlands. The stream occupies a glaciated valley, aligned west-east and has three main headwater tributaries with northerly, southerly and westerly aspects. Much of the stream network is fringed by riparian peatlands. Stream temperatures are mainly regulated by energy exchanges at the air-water interface. However, they are also influenced by inflows from the saturated riparian zone, where surface water source areas are strongly connected with the stream network. Consequently, the spatial distribution of stream temperatures exhibits limited variability. However, there are significant summer differences between the headwaters, despite their close proximity to each other. This is consistent with aspect (and incident radiation), with the south and west facing headwaters having higher temperatures. The largest, north-facing sub-catchment shows lower summer diurnal temperature variability, suggesting that lower radiation inputs dampen temperature extremes. Whilst stream water temperature regimes in the lower catchment exhibit little change along a $1 \mathrm{~km}$ reach, they are similar to those in the largest headwater; probably reflecting size and comparable catchment aspect and hydrological flow paths. Our results suggest that 
23 different parts of the channel network and its connected wetlands have contrasting

24 sensitivity to higher summer temperatures. This may be important in land management

25 strategies designed to mitigate the impacts of projected climatic warming.

27 Keywords: stream temperature, riparian zones, thermal regime, connectivity, moorland 28 hydrology, runoff processes.

$30 \quad$ 1. Introduction

31 Stream water temperature is a critical physical parameter in riverine ecosystems (Caissie

32 2006); it governs many biogeochemical and ecological processes which influence water

33 quality dynamics (Isaak and Hubert 2001) and stream metabolism (Izagirre et al. 2008;

34 Kaushal et al. 2010; Birkel et al. 2013). It has the capacity to influence life cycles of aquatic

35 organisms, such as determining the timing of fish spawning and the ability of organisms to

36 resist disease (Malcolm et al. 2008). Temperature is also known to be a fundamental control

37 on the distribution of organisms, as different species have contrasting tolerance to different

38 temperature ranges (Malcolm et al. 2004; Caissie 2006). Climate change projections imply

39 that even for low emission scenarios, both the winter and summer mean air temperatures

40 in Northern Britain will increase by $>1^{\circ} \mathrm{C}$ over the next 30 years; worse case scenarios

41 suggest $4^{\circ} \mathrm{C}$ increase (UKCP09 2009). Given that temperatures are largely controlled by

42 hydroclimatic drivers (e.g. net radiation fluxes), and modulated by the terrestrial

43 environment, these projections suggest that stream temperatures will increase, with

44 concomitant impacts on stream ecology and biogeochemistry likely (Hrachowitz et al. 2010). 
45 Controlling terrestrial environmental factors include shading, provided by riparian

46 vegetation and topography, elevation, groundwater contributions and stream channel

47 morphology (Imholt et al. 2013). Some of these factors can be manipulated to mitigate the

48 effects of climatic warming; this is a current area of policy development. Changes in stream

49 thermal regimes occur as a result of both the aforementioned natural influences, but also of

50 anthropogenic activity, for example, environmental change, reductions in flow,

51 deforestation/afforestation and direct thermal pollution (e.g. effluent discharges). These

52 may occur at all scales, from local, to regional, to global (Isaak et al. 2010; Ficklin et al.

53 2013).

54 In the UK, the headwaters of most large river systems drain upland areas of mountain and

55 moorland environments. In such streams, short term (hours to days) temperature dynamics

56 are driven by a combination of incoming solar radiation, stream flows, humidity and

57 evaporation (Sinokrot and Stefan 1994; Caissie 2006; Hannah et al. 2008; Brown et al. 2010).

58 Longer term variations (months, years etc.) are further influenced by reach characteristics

59 (Malcolm et al. 2004), e.g. seasonal changes to riparian shading (Isaak and Hubert 2001;

60 Hannah et al. 2008) and decadal to centurial lasting land management practices. The open

61 moorland settings of many UK headwater streams have resulted from historical tree

62 clearance and land management, which promote grazing of mammals (i.e. sheep (Ovis aries)

63 and red deer (Cervus elaphus) or shooting of game birds such as red grouse (Lagopus

64 lagopus scotica). These channels have limited shading as they often only have dwarf shrubs

65 and grasses bordering them (Brown et al. 2010). Here, surface energy exchanges such as

66 radiation inputs, air temperature, relative humidity and wind speed are the most important

67 factors influencing stream temperatures. These factors determine the heat exchanges at the 
68 air-water interface (e.g. evaporation, sensible, and latent heat). Heat exchange also occurs

69 at the water-channel bed interface as bed heat flux or loss and gain of net radiative energy.

70 The balance of these components is dynamic, varying both sub-daily and seasonally, with

71 many alternating between both heat sources and sinks (Hannah et al. 2008; Brown et al.

72 2010). Importantly, in such moorland locations, the daily means are often similar (Malcolm

73 et al. 2004), though the temperature extremes are greater (i.e. the maximum and minimum

74 water temperatures) (Hrachowitz et al. 2010) than in higher order watercourses, where

75 riparian tree cover increases (Hannah et al. 2008, Brown et al. 2010). This contrasts with

76 many studies in other regions which have shown that the daily minimum, maximum and

77 mean temperatures in headwater streams tend to be generally lower than larger rivers, as

78 the temperatures more closely reflect groundwater (Poole and Berman 2001; Caissie 2006).

79 Others have also found that water temperatures generally increase downstream reflecting

80 wider stream channels and less shading by vegetation than in forested headwaters (e.g.

81 Lewis et al. 2000; MacDonald et al. 2013a; Moore, Nelitz, and Parkinson 2013).

82 To date, there have been relatively few investigations into the thermal regimes of open

83 moorland streams. Previous work has largely focused on forest streams (e.g. Malcolm et al.

84 2004; Hannah et al. 2008; Brown et al. 2010) or alpine systems (Brown et al. 2006a; Brown

85 and Hannah 2008; Blaen et al. 2012). The small scale spatial and temporal variations of

86 thermal regimes in moorland channels and their associated hydrological source areas (e.g.

87 soil water and groundwater) and landscape controls have rarely been investigated. Given

88 the importance of such headwaters in providing ecosystem services to downstream river

89 systems (Bishop et al. 2008) and the likely impacts of climate change, it is imperative that 
90 we have a good understanding of the thermal regimes of such streams and their associated

91 controls.

92 In the Scottish Highlands, climate change projections indicate a likely warming of streams in 93 summer, which will be exacerbated by reduced low flows (Capell et al., 2013, 2014). Such 94 streams sustain aquatic ecosystems that have high conservation and economic value, with 95 internationally important populations of Atlantic salmon (Salmo salar) (Malcolm et al. 2008) 96 which may be threatened by warming. Consequently, there are proposals to mitigate the 97 effects in such streams by riparian planting, though the implications of afforestation on 98 ecosystem function are poorly understood (Birkel et al. 2013). Moreover, there is little 99 guidance as to where such planting could be most effective (Wilkerson et al. 2006; Gomi et 100 al. 2006).

101 Here, we examine small scale variability in stream temperatures and associated source 102 waters in the $3.2 \mathrm{~km}^{2}$ Bruntland Burn catchment in the Scottish Highlands. This is a tributary 103 of the $31 \mathrm{~km}^{2}$ Girnock catchment, a mainly moorland catchment that is a long-term 104 monitoring site for Atlantic salmon and has a history of stream temperature studies 105 (Hannah et al. 2008; Malcolm et al., 2008a). Previous work has shown a remarkable spatial 106 consistency of thermal regimes in the moorland part of the river network, with any 107 differences mainly due to the effect of riparian shading by trees in the lower $2 \mathrm{~km}$ reach of 108 the Girnock stream (Malcom et al., 2004). However, the thermal regime of the Bruntland 109 Burn exhibited more highly moderated temperatures than other sites in the catchment; in 110 addition to reduced diurnal variations, there are higher winter temperatures and lower 111 summer temperatures than the other sites (Malcolm et al., 2004). It was also shown that 112 there are subtle differences between the dominant runoff processes in the Bruntland and 
113 larger Girnock catchment; with proportionally higher groundwater contributions in the

114 former (Birkel et al. 2011), but also a strong influence of a large riparian wetland that

115 generates around $80 \%$ of the annual runoff (Tetzlaff et al., 2014). The current study aimed

116 to characterise and explain the spatial and temporal variability of stream water

117 temperatures within the Bruntland Burn catchment; the specific objectives were to:

118 1. Characterise any small scale spatial differences in water temperatures in the channel 119 network of the Bruntland Burn and the source areas draining into it.

1202 . Investigate the temporal variability and the catchment wide spatial differences at 121 both seasonal and 24 hour scales.

122 3. Examine the dominant controls on spatial and temporal variations in stream water 123 temperatures, particularly with respect to landscape structure and linked water 124 sources.

\section{$126 \quad \underline{\text { 2. Study Site }}$}

127 The Bruntland Burn is located in the Cairngorms National Park, Scotland, UK (Tetzlaff et al. 128 2007; Tetzlaff et al. 2014). In brief, the area has been glaciated and has over-widened, 129 gently sloping valley floors, receiving drainage from steeper hillslopes. The geology is mainly 130 granite in the most elevated areas, with associated metamorphic rocks fringing. The bedrock

131 is covered by various drift deposits (mainly poorly sorted till), which can be up to 40m deep 132 in the valley bottoms. Land cover in the Bruntland Burn is mostly heather (Calluna vulgaris) 133 dominated moorland, with limited forest cover (Figure 1a). The only significant riparian tree 134 shading is located at the catchment outlet, where a plantation fringes the southern side of 
135 the stream. Thereafter the channel becomes tree-lined up to its confluence with the Girnock

136 Burn. Upstream of this, dominant vegetation in the riparian zone includes Sphagnum spp.

137 mosses, dwarf shrubs (Myrica gale) and grasses (Molina caerulea). The channel is relatively

138 narrow (typically $<1 \mathrm{~m}$ ) and deep (up to $2 \mathrm{~m}$ in places) with overhanging vegetation, so in

139 summer, when the Myrica is in leaf and water levels are lower, the radiation flux to the

140 water surface is lower than might be expected.

141 A dominant feature of the catchment hydrology is that the riparian areas are mainly

142 comprised of organic soils (histosols), which are quasi-permanent saturation zones that can

143 be highly dynamic in their expansion and contraction (Figure 1b). The extent of the

144 saturated area ranges between $2-40 \%$ of the catchment, depending upon the antecedent

145 hydroclimatic conditions (Birkel et al. 2010). Around $80 \%$ of annual streamflow is generated

146 from overland flow and seepage from these areas, the remainder comes from deeper

147 groundwater discharge into the stream channel (Tetzlaff et al. 2014). Mean annual

148 precipitation (P) is approximately $1000 \mathrm{~mm}$ and mean annual evapotranspiration (ET) is

149 relatively low ( $400 \mathrm{~mm}$ ). Snow usually comprises $<10 \%$ of the annual P. Precipitation is

150 evenly distributed with limited seasonality and most falls in low intensity frontal events

151 ( $50 \%$ falls in events of $<10 \mathrm{~mm}$ ). Most events instigate a streamflow response, as water is

152 displaced via saturation-excess overland flow from the saturated riparian zones, which are

153 most of the time hydrologically connected to the channel network (Birkel et al. 2010).

154 Runoff coefficients are typically $<10 \%$, but these increase non-linearly in wetter periods to

155 around $>40 \%$, as the saturated zone in the valley bottom expands and connects lateral flow

156 in the podzolic soils on the steeper hillslope to the channel network (Tetzlaff et al. 2014). 
157 Mean annual air temperatures are about $6^{\circ} \mathrm{C}$, ranging between $12^{\circ} \mathrm{C}$ and $1^{\circ} \mathrm{C}$ in summer and

158 winter respectively.

159 The Bruntland Burn has three main headwaters with contrasting characteristics (Figure 1c):

160 Headwater One ( $\mathrm{HW} 1,0.65 \mathrm{~km}^{2}$ ) is south-facing and distinguished by a large mire in the

161 valley bottom; the edges of the mire receive groundwater seepage from the surrounding

162 hillslopes. Histosols cover $17 \%$ of this sub-catchment. The small stream draining HW1 has a

163 shallow gradient and predominantly pool-riffle morphology. In contrast, Headwater Two

$164\left(\mathrm{HW} 2,0.43 \mathrm{~km}^{2}\right.$ ) is a steep east-facing valley (average slope $15^{\circ}$ ) drained by a channel

165 dominated by a cascade morphology. Soils on the steep slopes are mainly podsols and

166 rankers, though histosols in the valley bottom cover $8 \%$ of the sub-catchment. Headwater

167 Three $\left(\mathrm{HW} 3,0.81 \mathrm{~km}^{2}\right.$ ), is the largest and drains a wetland-dominated cirque, where deep

168 peats (histosols) and shallow peats constitute $22 \%$ of the sub-catchment. The corrie base is

169 wide; the average slope of the catchment is $14^{\circ}$. Channel morphology is predominantly

170 step-pool, with pool-riffle becoming more common in the lower area close to the

171 confluence with main channel.

172 The confluence of these three headwaters is located in an over-widened glaciated valley,

173 orientated west-east with a large area of histosols fringing the main Bruntland Burn. In this

174 lower catchment, histosols cover $21.5 \%$ of the area. The dominant channel morphology

175 here is pool-riffle. As noted above, the lower stream channel is narrow with a low width-

176 depth ratio. This, together with a lack of riparian trees, means that most shading is due to

177 channel dimensions, aspect (West-East) and riparian shrub cover (Table 1). Throughout the

178 stream network there are point source influxes of surface water draining adjacent mires 
179 (Figure 1). These are active most of the year, and stop flowing only in the driest conditions 180 (Birkel et al. 2010).

181

$182 \quad$ 3. Data and methods

183 The monitoring period ran between $21^{\text {st }}$ June 2012 and $21^{\text {st }}$ September 2013 , though in 184 order to not produce a summer bias, all annual analysis was based on the period $1^{\text {st }}$ July 1852012 to $30^{\text {th }}$ June 2013. The monitoring period was chosen to allow seasonal comparison. 186 Seasons were defined astronomically (i.e. between solstice and equinox) based on the orbit 187 of the Earth.

188 Hydroclimatic data (precipitation, air temperatures, radiation, humidity and wind speed) 189 were measured at an automatic weather station (AWS) in the Girnock catchment, operated 190 by Marine Scotland Science (c.f. Hannah et al. 2004). Both discharge, calculated using an 191 established rating equation (with stage height derived from a capacitance water level 192 recorder in a rated natural section) and precipitation (using a Davis tipping bucket rain 193 gauge) were measured within the Bruntland Burn catchment, using Odyssey data recording 194 loggers at 15 minute intervals and averaged to hourly records.

195 Water temperature was measured using TinyTag TGP-4017 loggers (Gemini data loggers) 196 with internal thermistors of $0.5^{\circ} \mathrm{C}$ precision. They have a response time of 25 minutes 197 ("Temperature Loggers and Outdoor Data Loggers for Environmental Monitoring" 2013). 198 Due to logistical and physical constraints, a 1 hour recording interval was used to reduce the 199 download frequency, account for the response time and to control the quantity of data 200 produced. Data was also used from two CTD Divers (Schlumberger Water Services), precise 
201 to $0.1^{\circ} \mathrm{C}$. These were originally installed in the catchment in 2011 , as part of a separate

202 hydrology study. These also recorded every 15 minutes (and were averaged to one hour). All

203 loggers were calibrated across a range larger than field temperatures, before and after the

204 study period and were shown to be within $0.5^{\circ} \mathrm{C}$ accuracy.

205 The monitoring network represented a compromise between extensive spatial coverage, 206 and being logistically manageable. Eleven stream loggers were installed to measure 207 temperature; one in each of the headwater tributaries (HW1-HW3) and then at regular 208 distances along the main stem of the Burn (SW4-11) (Figure 1). Logistics and access 209 problems precluded installation at upstream sites in the tributaries, but data collected at 210 their lower points captured their thermal characteristics. Previous work showed that the

211 main deep groundwater influxes to the stream channel occurred along the wide, flat valley

212 bottom, downstream of the headwater confluence. The intense monitoring along the main

213 stem was therefore designed to detect effects of any major groundwater discharges as 214 winter "hot spots" or summer "cold spots". To measure deeper (>2m) groundwater 215 temperatures, one logger was located in an emerging spring (GW1) at the foot of the 216 northern slopes in the lower catchment. Three further loggers were situated in wells along a 217 hillslope transect (GW2-4) measuring shallower $(<2 \mathrm{~m})$ groundwater levels. This hillslope 218 transect has been the focus of detailed process studies on water flows paths and residence 219 times, particularly in the hydrologically dominant riparian saturation zone (Tetzlaff et al. 220 2014; Geris et al. 2014). To measure surface water temperatures in this critical riparian 221 zone, four loggers were positioned within connected perennial water tracks on the hillslope 222 (SFW1) and riparian zone (SFW2-4) (Figure 1). The stream water loggers were attached to 223 rocks and tethered to the bank, due to the lack of other available substrates and mainly 
224 peat bed and banks. The thermistors were shielded from radiation (Long and Jackson, 2013)

225 and positioned on the streambed. Stream loggers were placed in sections of deeper water

226 to reduce the chance of dewatering (Table 1). Given the small channel dimensions, relative

227 water velocities, lack of a hyporheic influence and earlier work by Imholt et al., (2013) the

228 effects of locational biasing was deemed unlikely to have a major effect.

229 Prior to statistical analysis, the data was manually checked and all spurious outliers (e.g.

230 dewatering during data download) were removed (Sowder and Steel 2012) to produce a set

231 of data free of errors. To investigate spatial differences in water temperatures mean,

232 maximum, minimum and standard deviation were calculated for each of the stream water

233 (HW1-3 and SW4-11) and groundwater (GW1-4) loggers for the whole study period and

234 then for each of the seasons (including summer 2012). Degree days were calculated for each

235 of the stream water locations as another way of visualising the differences, as they

236 represent the sum of temperatures above the base level of $0^{\circ} \mathrm{C}$. In addition, we also carried

237 out Kruskall-Wallis tests (Hollander, Wolfe, and Chicken 2013) and Wilcoxon signed-rank

238 tests (Hollander, Wolfe, and Chicken 2013). These were selected as they are non-parametric

239 tests, to compare the medians of non-normally distributed data sets. Because of the nature

240 of stream water and its down-stream interdependence, we used the maximum

241 instantaneous temperature recorded per day as well as the median. The reason for this was

242 that previous work on spatially distributed temperature sensors in the Girnock had shown

243 that differences were most apparent in the upper ranges, whilst lower temperatures were

244 constrained by freezing, and medians were similar between sites.

245 The Kruskall-Wallis test was run using the full data set from July 2012 - July 2013 for all 246 sites, as well as just the daily maximum temperatures. In addition, we ran the Wilcoxon test 
247 on paired loggers moving downstream as a post-hoc test for the variability between them, 248 using a Bonferroni correction (Holm 1979) to adjust the $p$ values. These tests assume that 249 the data are independent, which is not strictly true in stream temperature studies, thus the 250 results must be interpreted cautiously. The analysis then focussed on selected loggers 251 (loggers HW1, HW2, HW3, SW5, SW9 and SW11) that summarized the thermal regime of 252 the stream network and produced reasonable spatial distribution (see Figure 1), which then 253 allowed more analysis at sub-seasonal scales.

254 To further assess differences between locations, seasonal temperature-duration curves 255 (Brown et al. 2006b) were derived showing the percentage of time a particular temperature 256 was equalled or exceeded. Based on the hydrometric data, we also calculated time-series of 257 the extent of catchment saturation, using the algorithm (based on precipitation, antecedent 258 wetness and a soil moisture parameter over the previous seven days) developed by Birkel et 259 al., (2010). This was coupled with the available precipitation data and discharge data as a 260 measure of antecedent wetness, and as a proxy for the source areas of water within the 261 stream, on which incoming radiation can act. This characterisation of the catchment's 262 wetness allowed the selection of contrasting 24 hour periods throughout the year. These 263 were categorised as warm/wet, warm/dry, cold/wet and cold/dry. Temperatures for HW1-3, 264 SW11, SFW3 \& 4, GW1 and air temperature were investigated for each of the periods: 265 cold/dry on $9^{\text {th }}$ November 2012 (mean air T $6.8^{\circ} \mathrm{C}$, mean daily Q $0.03 \mathrm{~m}^{3} \mathrm{~s}^{-1}$, daily P Omm and 266 saturation extent 7\%); cold/wet on $1^{\text {st }}$ February 2013 (mean air T $1.6^{\circ} \mathrm{C}$, mean daily Q 0.17 $267 \mathrm{~m}^{3} \mathrm{~s}^{-1}$, daily P $1 \mathrm{~mm}$ and saturation extent $33 \%$ ); warm/dry on $8^{\text {th }}$ September 2012 (mean air $268 \mathrm{~T} 15.6^{\circ} \mathrm{C}$, mean daily $\mathrm{Q} 0.024 \mathrm{~m}^{3} \mathrm{~s}^{-1}$, daily $\mathrm{P} 0 \mathrm{~mm}$ and saturation extent $2 \%$ ); warm/wet on 
$26927^{\text {th }}$ August 2012 (mean air $\mathrm{T} 12.6^{\circ} \mathrm{C}$, mean daily $\mathrm{Q} 0.04 \mathrm{~m}^{3} \mathrm{~s}^{-1}$, daily $\mathrm{P} 12.6 \mathrm{~mm}$ and 270 saturation extent $7 \%)$.

271

\section{4. Results}

$273 \quad$ 4.1 Hydroclimatological context

274 Air temperatures followed expected seasonal patterns, reflecting incoming radiation (Figure

$2752 \mathrm{a}$ and b). However, a cool, wet summer in 2012 was followed by an unusually cold winter 276 and spring in 2013 (Figure 2b), with below-average temperatures persisting until April (Met 277 Office 2013a; 2013b). This also corresponded with long periods of snow cover and ground 278 frost which coincided with intermittent partial freezing of the upper soils $(<5 \mathrm{~cm})$ and the 279 stream surface. Warmer spells in mid-December 2012 and late February 2013 led to snow 280 melt and substantial increases in discharge of up to $16 \mathrm{~mm}$ per day, which was the highest 281 discharge observed (Figure 2d). Whilst the summer of 2012 was the wettest for 100 years, 282 summer 2013 was the driest and warmest for 10 years (Met Office 2012; Met Office 2013c). 283 The extent of the saturated riparian zone (as a percentage of catchment area) was 284 calculated using an algorithm that expressed antecedent conditions as a function of 285 evapotranspiration (ET) and precipitation (Birkel et al. 2010). During the wetter periods (e.g. 286 winter 2012-2013) the saturation extent was $>40 \%$ (Figure 2e). In summer with higher 287 temperatures, saturation extent remained $<20 \%$ and was $<5 \%$ for sub-monthly periods.

288 
290 Spatially, the average, range and dynamics of stream water temperatures are very similar

291 throughout the catchment (Table 2 and Figure 3). Differences between the three

292 headwaters become apparent only during the summer periods, when temperatures are

293 highest. HW1 had the largest variations in temperature and a slightly higher mean. HW2 had

294 the highest maximum temperature but a slightly smaller standard deviation than HW1. In

295 contrast, HW3 showed the most damped dynamics (low standard deviations) and lowest

296 mean temperature. Degree day analysis correspondingly showed similar patterns between

297 the headwaters; HW3 had the lowest and HW1 the highest. The minimum temperatures for

298 all sites were similar and within the precision of the instrumentation, they remained in

299 liquid water throughout the period.

300 Mean stream water temperatures, downstream of the headwater confluence, (locations

301 SW4-11) remained relatively constant, though they were closest in range to HW3 and did

302 not exhibit the extreme high temperatures of HW2 and HW3. Only SW10 deviated

303 substantially with a lower mean and maximum temperature. This site is downstream of the

304 inflow of the groundwater spring monitored at GW1. The annual degree days for the post

305 confluence sites also showed relative homogeneity, though they were lowest of all sites at

306 SW10 (Table 2).

307 Of the groundwater sites, GW1 exhibited remarkable thermal constancy and had the highest

308 median. Shallower subsurface water at the upslope sites (GW2 and 3) had greater variability

309 (Figures 3 and 4, Table 2). These dynamics differed from stream waters, in terms of a

310 reduced range, though the medians of GW2 and 3 were close to the stream sites. GW4

311 (situated in the riparian peats where the water table remains within $20 \mathrm{~cm}$ of the soil

312 surface) had lower variation, showed higher mean and minimum, but lower maximum 
313 temperature than sites further up the hillslope (where the water table depth varies between

$31420 \mathrm{~cm}$ to $>1 \mathrm{~m}$ below the surface).

315 The riparian surface water loggers (SFW3 \& SFW4) had similar median temperatures to 316 stream water. The variation of these surface waters was higher than the stream water 317 temperatures along the main stem. SFW3 showed similar temperatures to the main 318 channel, and SFW4, situated in the riparian zone further upstream from SFW3, showed the 319 greatest temperature variability of all surface water loggers, largely as a result of occasional 320 winter freezing (Figure 3 and Figure 4).

321 Results of the statistical tests showed that there were no statistically significant differences 322 between the medians of stream water sites $(p>0.05)$. However, for the maximum daily 323 temperatures showed a significant difference $(p=<0.05)$ with HW3 being different to HWs1 324 and 2. The tests also confirmed the difference of the four GW sites from the stream water 325 sites $(p<0.5)$, whilst there was no pairwise difference between the stream water site at 326 SW11 and the four SFW loggers.

\section{$328 \quad 4.3$ Seasonal variability in water temperatures}

329 The seasonality of weekly stream temperatures showed similar temporal variations at the 330 headwater sites and the sites along the main stem (Figure 5, Table 3). The main stem (SW4331 11) showed no significant inter-site seasonal variation (Table 3) and exhibited similar 332 variability during all seasons. HW3, which had the lowest variability in all seasons, was most 333 similar to the main stem sites. The most apparent differences were the higher summer 334 temperatures in HW1 and HW2. 
335 Temperature exceedance curves show the integrated effect of these seasonal changes;

336 differences are most clear during summer (Figure 6). HW3's lower summer temperatures

337 and variability is apparent, as is the intermediate distribution of main stem summer stream

338 temperatures plotting between HW1\&2 and HW3. During autumn 2012, the upper portion

339 of the curves for all sites was similar, with the tail of the distribution showing separation,

340 and HW3 being warmer than HW2 and HW1 as temperatures dropped (Figure 6a). During

341 winter and spring (Figure $6 \mathrm{~b}$ and $\mathrm{c}$ ), the duration curves converged with little difference,

342 though in spring the warmer temperatures in HW1 began to become apparent. The warm,

343 dry summer of 2013 (Figure 6d) had higher temperature extremes than the cooler, wetter

344 summer of 2012 (Figure 6e), with inter-site differences becoming more evident as

345 temperatures increased, particularly in 2013. In this latter year (Figure 6d), HW2 had the

346 steepest and HW3 the shallowest curve. During such warm conditions, temperatures in the

347 riparian surface water sites (SFW) tend to be higher than HW3, but cooler than HW1 \& 2 .

348

349 4.4. Diurnal variability in water temperature

350 Temperatures during four 24 hour periods (Figures 7-10) give examples of the typical diurnal

351 variations of the stream waters and representative source waters. These show fairly

352 consistent differences in the diurnal cycles of the 3 headwaters, in relation to the main stem

353 sites. The 24 hour periods exemplify contrasting antecedent and hydroclimatic conditions:

354 cold and wet ( $1^{\text {st }}$ February 2013$)$, cold and dry $\left(9^{\text {th }}\right.$ November 2012$)$, warm and wet $\left(28^{\text {th }}\right.$

355 August 2012) and warm and dry ( $8^{\text {th }}$ September 2012). Stream temperatures in the lower

356 catchment (SW sites) usually fall between HW1\&2 and HW3, but are also similar to the SFW 
357 sites. The deep groundwater (GW 1) remains constant throughout each 24 hour period 358 considered.

359 The cold/wet period (Figure 7a) exhibited the least spatial variability between sites. Water 360 at all sites was super-cooled and close to $0^{\circ} \mathrm{C}$. Over the 24 hours, air temperature dropped 361 steadily (Figure 7b). Of the headwater sites, HW3 exhibited the highest maximum 362 temperature and HW1, the lowest. In the main stem, SW11 showed the highest peak $(\sim 1.5$ $363{ }^{\circ} \mathrm{C}$ ) of all, with the peak around $3 \mathrm{pm}$ approximately 2 hours after the headwaters. SFW3 364 remained more constant, at around $1.5^{\circ} \mathrm{C}$, and showed similar levels and patterns as the 365 streams and remained above air temperature during the afternoon. SFW4 showed greatest 366 variability.

367 The cold, dry 24 hour period occurred at the end of a dry autumn. Air temperature (Figure 368 8) showed modest variability, but a decrease in the evening of $\sim 4{ }^{\circ} \mathrm{C}$. Stream temperatures 369 varied between 4.5 and $6.5^{\circ} \mathrm{C}$ (Figure 8a). HW3 showed the least variability and HW2 the 370 greatest. SW11's diel curve was most similar to the shape and magnitude of HW3. Both 371 HW1 and HW3 reached thermal maxima around 14:00, several hours after HW2. This was 372 also about 2 hours before the peak of SW11, at the catchment outlet, and several hours 373 after the peak at surface water site SFW3. This site showed the least variability in surface 374 water temperatures, with temperatures being slightly cooler than stream water, though the 375 variability in SFW4 was similar to the stream.

376 The wet, warm period in August 2012 had stream water temperatures ranging from around $37710^{\circ} \mathrm{C}$ to $12^{\circ} \mathrm{C}$ (Figure 9a); air temperatures varied between $9^{\circ} \mathrm{C}$ and $14^{\circ} \mathrm{C}$. HW3 had the 378 lowest variation $\left(\sim 1^{\circ} \mathrm{C}\right)$. The highest maximum $\left(>12^{\circ} \mathrm{C}\right)$ was at $\mathrm{HW} 2 . \mathrm{HW} 1$ was intermediate 379 but had the lowest minimum value. Thermal maxima at all sites occurred at 16:00. Both 
380 HW3 and SW11 had very similar magnitude diel variations, with HW3 generally having a

381 slightly lower maximum and higher minimum values. Surface water temperatures exhibited

382 slightly higher values and variability was higher at SFW4, but lower at SFW3. Day-time peaks

383 occurred slightly before stream water temperature at SW11 peaked.

384 Warm, dry conditions in September 2012 saw air temperature ranges from $7^{\circ} \mathrm{C}$ to $>20^{\circ} \mathrm{C}$

385 (Figure 10). Again, HW3 showed least variability (range $<2.0^{\circ} \mathrm{C}$ ) and HW1 the greatest (range

$386 \sim 5^{\circ} \mathrm{C}$ ). The daily maxima for the three headwaters occurred simultaneously $(15: 00)$ with

387 SW11 being about 2 hours later. As with other periods, SFW3 showed lower variability with

388 a lower magnitude curve, more similar to stream waters than SFW4, which was more 389 pronounced like the diurnal air temperature curve.

390 5. Discussion and wider implications

391 Many studies have examined interactions between landscape structures and stream

392 temperatures (Malcolm et al. 2004; Hannah et al. 2008; Malcolm et al. 2008; Brown et al.

393 2010), though some have been based in very different geographical settings to the one in

394 this study (Brown et al. 2006a; Brown and Hannah 2008; Isaak et al. 2010; Mayer 2012;

395 Blaen et al. 2012; Leach and Moore 2013). However, all have highlighted heterogeneities

396 that can occur in stream thermal regimes, with differences in controls at contrasting

397 temporal and spatial scales (Webb and Walling 1985).

398 The first obvious finding of the study was the general similarities in stream water

399 temperatures, throughout the catchment, for most of the period. Only during the summer

400 months did differences between any stream water sites become apparent and statistically

401 significant. This was largely restricted to the south-facing HW1 and east facing HW2 sub- 
402 catchments and showed higher maximum temperatures. Correspondingly, it seems that 403 HW3 has a disproportionate influence on the thermal regime of the lower catchment 404 downstream of the confluence of the three tributaries, as its annual range seasonal 405 variations and diurnal dynamics were most similar to the main stem sites. On the one hand, 406 this probably simply reflects the larger size and, therefore, likely higher discharge and higher 407 thermal capacity (Constantz et al. 1994). Additionally, the characteristics of HW3 and the 408 lower catchment have many similarities, including large north-facing areas, similar 409 distributions of soils and drift and similar landscape structure in terms of riparian saturated 410 zones. This is likely to result in a similar relative importance of runoff generation processes 411 (Tetzlaff et al. 2007). Such influence of different runoff sources on stream thermal regimes 412 has been previously shown (R. D. (Dan) Moore 2006; Mayer 2012; MacDonald et al. 2013b; 413 Imholt et al. 2013). Runoff generation in the Bruntland Burn is dominated by near surface 414 flow paths - particularly overland flow from peaty soils - which maintain strong hydrological 415 connectivity with the channel network. These extensive areas of saturation act, not only as 416 hydrological source areas, but as a water-air interface for energy exchange additional to the 417 actual channel network (Janisch et al. 2012). This is consistent with the finding that the 418 surface water sites have similar thermal regimes to stream water sites.

419 Groundwater inflows have been shown to have a moderating effect on steam water 420 temperatures in many locations (e.g. Webb and Walling 1985; MacDonald et al. 2013). The 421 groundwater temperatures at GW1 are clearly very stable throughout the year, due to the 422 insulation effects of surface sediments (soil, glacial drift etc; (Figura et al. 2011). However, in 423 the Bruntland Burn up to $40 \%$ of annual runoff is generated by hillslope groundwater 424 discharging into the riparian wetlands (Tetzlaff et al. 2014), thus facilitating an opportunity 
425 for atmospheric energy exchanges to occur, before water reaches the stream channel.

426 Indeed, the groundwater wells in the riparian zone showed that temperatures in shallower

427 groundwater had more variable thermal regimes, reflecting the greater influence of 428 atmospheric energy exchanges (Kurylyk et al. 2013). The contribution of deeper 429 groundwater discharge directly into the stream channel network is low (around 19\% of 430 annual runoff) (Birkel et al. 2011). Its influence is most apparent during winter when heat 431 transfer into streams can account for up to $30 \%$ of inputs - as atmospheric energy inputs 432 are low - and probably prevent the stream from freezing (Hannah et al., 2004). 433 Nevertheless, the effects of the spring, monitored at GW1, on stream temperatures is 434 evident at SW10, which has the lowest degree days of all stream water sites.

435 Aside from SW10, the thermal regimes of the monitoring sites in the lower part of the 436 catchment, along the main stem of the stream channel, are consistent and lacking in 437 variability. In addition to the similar catchment characteristics and runoff sources as HW3, in 438 summer, this may also, to some extent, reflect the low width:depth ratio of the channel 439 (Sinokrot and Stefan 1993; Hawkins et al. 1997; Arscott et al. 2001; Long and Jackson 2013) 440 and the riparian cover of shrubs. This would mitigate further warming by limiting incident 441 short wave radiation and moderate night time cooling by back scatter of long wave (Hannah 442 et al. 2008; Malcolm et al. 2008).

443 The thermal regimes monitored in stream water in the Bruntland Burn largely reflect the 444 dominance of hydroclimatic controls at inter-annual, seasonal and diurnal scales, which give 445 overall similarity between sites. The most obvious difference is that the spatial variability in 446 stream water primarily reflects aspect (and the resulting influence on energy inputs), with 447 the three headwater streams having the most marked differences in thermal regimes in 
448 summer. The importance of aspect as a landscape factor in the moderation of atmospheric 449 exposure is well documented (e.g Cadbury et al., 2008; Quinton and Carey, 2008; Janisch et 450 al., 2012) among others. The south-facing HW1 is generally the most variable, whilst the 451 east facing HW2 exhibits the highest summer maxima, particularly in 2013. This may also 452 affect hydrological influences, as flows (although unmeasured) were observed to be very 453 low from this sub-catchment, during the 2013 drought period, and this will have affected 454 the thermal capacity of this stream (Sinokrot and Gulliver 2000; Caissie 2006; Orr et al. 455 2014). HW3 has the most moderated thermal regime, with attenuated maxima and minima 456 and the lowest range through autumn, spring, and summer.

457 Projections indicate that there is likely to be large scale warming of streams, due to the 458 effects of climate change, on un-forested headwater streams in the northern UK, by the 459 middle of the $21^{\text {st }}$ Century (Hrachowitz et al. 2010). Our results suggest that an 460 understanding, of small scale, subtle spatial differences in summer stream water 461 temperature, is likely to be important in impact assessment for small moorland catchments, 462 like the Bruntland Burn. Such understanding enables the evaluation of the implications of 463 changing meteorological conditions on small headwater catchments, in which the thermal 464 heterogeneity can be substantial (e.g. in sub-catchment comparisons) at higher 465 temperatures. Here lethal or sub-lethal effects may occur on organisms adapted to colder 466 water upland streams. As upland streams are often important nursery streams for Atlantic 467 salmon (Salmo salar), concerns over projected temperature increases have resulted in the 468 promotion of riparian tree planting as an ameliorative measure (Rutherford et al. 1997; 469 Broadmeadow et al. 2011). Given the likely importance of the water-air interface on 
470 saturated peaty soils, more extensive buffer strips that result in natural tree cover in such a

471 saturated area may need to be considered, to achieve temperature amelioration goals.

472 These preliminary results provide a basis for using more quantitative methods focusing on 473 analyses of temporal and spatial distributions of land/water-energy exchanges, for example, 474 using LIDAR in conjunction with daily assessment of solar position to account for effects of 475 aspect, hillslope and channel shading. Additionally, groundwater models are being used to 476 simultaneously track water and heat fluxes, to assess the overall effect of direct and indirect 477 groundwater fluxes (Kurylyk, Bourque, and MacQuarrie 2013b). Finally, whilst increasing 478 riparian shading to improve the thermal habitat for juvenile salmonids is a current target of 479 some land management strategies, there are wider ecosystem effects on other components 480 of aquatic function that need to be assessed.

\section{$482 \quad \underline{6 . \text { Conclusions }}$}

483 This study investigated the spatial and temporal variations in stream water temperatures in 484 a small headwater catchment. We conclude that:

- Stream waters within the catchment have very similar thermal regimes; the main 486 differences are restricted to differing summer high temperatures in three headwater 487 sub-catchments with contrasting aspect.

488 - The largest headwater catchment (HW3) appears to have a dominant influence on 489 the lower catchment which reflects both the size of HW3 but also the similarities in $490 \quad$ water sources, mitigation effects of the saturated riparian zones. 
- The temperature profile of the stream in the lower catchment appears to be strongly influenced by the energy balance of the source areas (e.g. riparian saturation zones

\section{Acknowledgements:}

lain Malcolm and staff at Marine Scotland (Pitlochry) are thanked for the provision of data

from the AWS.

\section{References}

Arscott, David B, Klement Tockner, and J V Ward. 2001. "Thermal Heterogeneity along a Braided Floodplain River (Tagliamento River, Northeastern Italy)." Canadian Journal of Fisheries and Aquatic Sciences 58 (12): 2359-73. doi:10.1139/f01-183.

Birkel, C., D. Tetzlaff, S. M Dunn, and C. Soulsby. 2009. "Towards a Simple Dynamic Process Conceptualization in Rainfall-runoff Models Using Multi-criteria Calibration and Tracers in Temperate, Upland Catchments." Hydrological Processes 24 (3): 260-75. doi:10.1002/hyp.7478.

Birkel, C., D. Tetzlaff, S. M. Dunn, and C. Soulsby. 2010. "Towards a Simple Dynamic Process Conceptualization in Rainfall-runoff Models Using Multi-Criteria Calibration and Tracers in Temperate, Upland Catchments." Hydrological Processes 24 (3): 260-75. doi:10.1002/hyp.7478.

Birkel, Christian, Chris Soulsby, lain Malcolm, and Doerthe Tetzlaff. 2013. "Modeling the Dynamics of Metabolism in Montane Streams Using Continuous Dissolved Oxygen Measurements." Water Resources Research 49 (9): 5260-75. doi:10.1002/wrcr.20409.

Birkel, Christian, Doerthe Tetzlaff, Sarah M. Dunn, and Chris Soulsby. 2011. "Using Time Domain and Geographic Source Tracers to Conceptualize Streamflow Generation Processes in Lumped Rainfall-Runoff Models." Water Resources Research 47 (February): 15 PP. doi:201110.1029/2010WR009547.

Bishop, K., I. Buffam, M. Erlandsson, J. Fölster, Hjalmar Laudon, Jan Seibert, and J. Temnerud. 2008. "Aqua Incognita: The Unknown Headwaters." Hydrological Processes 22 (8): 1239-42.

Blaen, Phillip J., David M. Hannah, Lee E. Brown, and Alexander M. Milner. 2012. "Water Temperature Dynamics in High Arctic River Basins." Hydrological Processes, n/a-n/a. doi:10.1002/hyp.9431. 
523 Broadmeadow, S. B., J. G. Jones, T. E. L. Langford, P. J. Shaw, and T. R. Nisbet. 2011. "The

524

525

526

527

528

529

530

531

532

533

534

535

536

537

538

539

540

541

542

543

544

545

546

547

548

549

550

551

552

553

554

555

556

557

558

559 Influence of Riparian Shade on Lowland Stream Water Temperatures in Southern England and Their Viability for Brown Trout." River Research and Applications 27 (2): 226-37. doi:10.1002/rra.1354.

Brown, L. E., L. Cooper, J. Holden, and S. J. Ramchunder. 2010. "A Comparison of Stream Water Temperature Regimes from Open and Afforested Moorland, Yorkshire Dales, Northern England." Hydrological Processes 24 (22): 3206-18.

Brown, Lee E., and David M. Hannah. 2008. "Spatial Heterogeneity of Water Temperature across an Alpine River Basin." Hydrological Processes 22 (7): 954-67. doi:10.1002/hyp.6982.

Brown, Lee E., David M. Hannah, and Alexander M. Milner. 2006a. "Thermal Variability and Stream Flow Permanency in an Alpine River System." River Research and Applications 22 (4): 493-501. doi:10.1002/rra.915.

- - . 2006b. "Hydroclimatological Influences on Water Column and Streambed Thermal Dynamics in an Alpine River System." Journal of Hydrology 325 (1-4): 1-20. doi:10.1016/j.jhydrol.2005.09.025.

Cadbury, S. L., D. M. Hannah, A. M. Milner, C. P. Pearson, and L. E. Brown. 2008. "Stream Temperature Dynamics within a New Zealand Glacierized River Basin." River Research and Applications 24 (1): 68-89. doi:10.1002/rra.1048.

Caissie, D. 2006. "The Thermal Regime of Rivers: A Review." Freshwater Biology 51 (8): 1389-1406. doi:10.1111/j.1365-2427.2006.01597.x.

Capell, R., D. Tetzlaff, R. Essery, and C. Soulsby. 2014. "Projecting Climate Change Impacts on Stream Flow Regimes with Tracer-Aided Runoff Models-Preliminary Assessment of Heterogeneity at the Mesoscale." Hydrological Processes 28 (3): 545-58.

Capell, R., D. Tetzlaff, and C. Soulsby. 2013. "Will Catchment Characteristics Moderate the Projected Effects of Climate Change on Flow Regimes in the Scottish Highlands?" Hydrological Processes 27 (5): 687-99. doi:10.1002/hyp.9626.

Constantz, Jim, Carole L. Thomas, and Gary Zellweger. 1994. "Influence of Diurnal Variations in Stream Temperature on Streamflow Loss and Groundwater Recharge." Water Resources Research 30 (12): 3253-64.

Ficklin, Darren L., Iris T. Stewart, and Edwin P. Maurer. 2013. "Effects of Climate Change on Stream Temperature, Dissolved Oxygen, and Sediment Concentration in the Sierra Nevada in California." Water Resources Research 49 (5): 2765-82. doi:10.1002/wrcr.20248.

Figura, Simon, David M. Livingstone, Eduard Hoehn, and Rolf Kipfer. 2011. "Regime Shift in Groundwater Temperature Triggered by the Arctic Oscillation." Geophysical Research Letters 38 (23): n/a-n/a. doi:10.1029/2011GL049749. 
Geris, Josie, Doerthe Tetzlaff, Jeffrey McDonnell, and Chris Soulsby. 2014. "The Relative Role of Soil Type and Tree Cover on Water Storage and Transmission in Northern Headwater Catchments." Hydrological Processes. http://onlinelibrary.wiley.com/doi/10.1002/hyp.10289/full.

Gomi, Takashi, R. Dan Moore, and Amod S. Dhakal. 2006. “Headwater Stream Temperature Response to Clear-Cut Harvesting with Different Riparian Treatments, Coastal British Columbia, Canada." Water Resources Research 42 (8): W08437. doi:10.1029/2005WR004162.

Hannah, D.M., I.A. Malcolm, C. Soulsby, and A.F. Youngson. 2004. "Heat Exchanges and Temperatures within a Salmon Spawning Stream in the Cairngorms, Scotland: Seasonal and Sub-Seasonal Dynamics." River Research and Applications 20 (6): 63552.

Hannah, David M., lain A. Malcolm, Chris Soulsby, and Alan F. Youngson. 2008. "A Comparison of Forest and Moorland Stream Microclimate, Heat Exchanges and Thermal Dynamics." Hydrological Processes 22 (7): 919-40. doi:10.1002/hyp.7003.

Hawkins, Charles P., James N. Hogue, Lynn M. Decker, and Jack W. Feminella. 1997. "Channel Morphology, Water Temperature, and Assemblage Structure of Stream Insects." Journal of the North American Benthological Society 16 (4): 728-49. doi:10.2307/1468167.

Hollander, Myles, Douglas A. Wolfe, and Eric Chicken. 2013. Nonparametric Statistical Methods. Vol. 751. John Wiley \& Sons. http://books.google.co.uk/books?hl=en\&lr=\&id=gYIKAgAAQBAJ\&oi=fnd\&pg=PP1\&d $\mathrm{q}=$ Nonparametric+Statistical+Methods\&ots=JZolS4at81\&sig=Xbyde1RNF99_hyeD_l BNOGG89c.

Holm, Sture. 1979. “A Simple Sequentially Rejective Multiple Test Procedure." Scandinavian Journal of Statistics, 65-70.

Hrachowitz, Markus, C. Soulsby, C. Imholt, I. A. Malcolm, and D. Tetzlaff. 2010. "Thermal Regimes in a Large Upland Salmon River: A Simple Model to Identify the Influence of Landscape Controls and Climate Change on Maximum Temperatures." Hydrological Processes 24 (23): 3374-91. doi:10.1002/hyp.7756.

Imholt, C., C. Soulsby, I. A. Malcolm, M. Hrachowitz, C. N. Gibbins, S. Langan, and D. Tetzlaff. 2013. "Influence of Scale on Thermal Characteristics in a Large Montane River Basin." River Research and Applications 29 (4): 403-19. doi:10.1002/rra.1608.

Isaak, Daniel J., and Wayne A. Hubert. 2001. "A Hypothesis About Factors That Affect Maximum Summer Stream Temperatures Across Montane Landscapes1." JAWRA Journal of the American Water Resources Association 37 (2): 351-66. doi:10.1111/j.1752-1688.2001.tb00974.x.

Isaak, Daniel J., Charles H. Luce, Bruce E. Rieman, David E. Nagel, Erin E. Peterson, Dona L. Horan, Sharon Parkes, and Gwynne L. Chandler. 2010. "Effects of Climate Change 

and Wildfire on Stream Temperatures and Salmonid Thermal Habitat in a Mountain River Network." Ecological Applications 20 (5): 1350-71. doi:10.1890/09-0822.1.

601

602

603

604

605

606

607

608

609

610

611

612

613

614

615

616

617

618

619

620

621

622

623

624

625

626

627

628

629

630

631

632

633

634

635

636

Izagirre, Oihana, Urko Agirre, Miren Bermejo, Jesús Pozo, and Arturo Elosegi. 2008. "Environmental Controls of Whole-Stream Metabolism Identified from Continuous Monitoring of Basque Streams." Journal of the North American Benthological Society 27 (2): 252-68.

Janisch, Jack E., Steven M. Wondzell, and William J. Ehinger. 2012. "Headwater Stream Temperature: Interpreting Response after Logging, with and without Riparian Buffers, Washington, USA." Forest Ecology and Management 270 (April): 302-13. doi:10.1016/j.foreco.2011.12.035.

Kaushal, S. S., G. E. Likens, N. A. Jaworski, M. L. Pace, A. M. Sides, D. Seekell, K. T. Belt, D. H. Secor, and R. L. Wingate. 2010. "Rising Stream and River Temperatures in the United States." Frontiers in Ecology and the Environment 8 (9): 461-66.

Kurylyk, B. L., C. P.-A. Bourque, and K. T. B. MacQuarrie. 2013a. "Potential Surface Temperature and Shallow Groundwater Temperature Response to Climate Change: An Example from a Small Forested Catchment in East-Central New Brunswick (Canada)." Hydrol. Earth Syst. Sci. 17 (7): 2701-16. doi:10.5194/hess-17-2701-2013.

Leach, J. A., and R. D. Moore. 2013. "Winter Stream Temperature in the Rain-on-Snow Zone of the Pacific Northwest: Influences of Hillslope Runoff and Transient Snow Cover." Hydrology and Earth System Sciences Discussions 10 (10): 12951-3. doi:10.5194/hessd-10-12951-2013.

Lewis, T. E., D. R. Lamphear, D. R. McCanne, A. S. Webb, J. P. Krieter, and W. D. Conroy. 2000. Regional Assessment of Stream Temperatures across Northern California and Their Relationship to Various Landscape-Level and Site-Specific Attributes. Humboldt State University Foundation. http://wvvvv.krisweb.com/biblio/ncc_hsu_lewisetal_2000_fspregass.pdf.

Lynsey Long, S., and C. Rhett Jackson. 2013. "Variation of Stream Temperature among Mesoscale Habitats within Stream Reaches: Southern Appalachians." Hydrological Processes, n/a-n/a. doi:10.1002/hyp.9818.

MacDonald, Ryan J., Sarah Boon, James M. Byrne, and Uldis Silins. 2013a. "A Comparison of Surface and Subsurface Controls on Summer Temperature in a Headwater Stream." Hydrological Processes, n/a-n/a. doi:10.1002/hyp.9756.

- - . 2013b. "A Comparison of Surface and Subsurface Controls on Summer Temperature in a Headwater Stream." Hydrological Processes, n/a-n/a. doi:10.1002/hyp.9756.

Malcolm, I. A., D. M. Hannah, M. J. Donaghy, C. Soulsby, and A. F. Youngson. 2004. "The influence of riparian woodland on the spatial and temporal variability of stream water temperatures in an upland salmon stream." Hydrology and Earth System Sciences Discussions 8 (3): 449-59. 
Malcolm, I. A., C. Soulsby, D. M. Hannah, P. J. Bacon, A. F. Youngson, and D. Tetzlaff. 2008.

Met Office, FitzRoy Road. 2012. "Summer 2012". Reference. Met Office. "The Influence of Riparian Woodland on Stream Temperatures: Implications for the Performance of Juvenile Salmonids." Hydrological Processes 22 (7): 968-79. doi:10.1002/hyp.6996.

Mayer, Timothy D. 2012. "Controls of Summer Stream Temperature in the Pacific Northwest." Journal of Hydrology. http://www.sciencedirect.com/science/article/pii/S0022169412008864.

646

-- . 2013a. "Winter 2012/13". Reference. Met Office. http://www.metoffice.gov.uk/climate/uk/summaries/2012/summer.

648

- - . 2013b. "Spring 2013". Reference. Met Office. http://www.metoffice.gov.uk/climate/uk/summaries/2013/spring.

650

- - . 2013c. "Summer 2013". Reference. Met Office.

651

652

653

654

655

656

657

658

659

660

661

662

663

664

665

Sinokrot, B.A., and H.G. Stefan. 1993. "Stream Temperature Dynamics: Measurements and Modeling." Water Resources Research 29 (7): 2299-2312. Temperatures." Journal of Hydraulic Research 38 (5): 339-49. 
674 Sowder, Colin, and E. Ashley Steel. 2012. "A Note on the Collection and Cleaning of Water Temperature Data." Water 4 (4): 597-606. doi:10.3390/w4030597.

676

677

678

"Temperature Loggers and Outdoor Data Loggers for Environmental Monitoring." 2013. Geminidataloggers.com. Accessed December 17.

http://www.geminidataloggers.com/data-loggers/tinytag-plus-2/tgp-4017.

Tetzlaff, D., C. Birkel, J. Dick, J. Geris, and C. Soulsby. 2014. “Storage Dynamics in Hydropedological Units Control Hillslope Connectivity, Runoff Generation and the Evolution of Catchment Transit Time Distributions." Water Resources Research, n/an/a. doi:10.1002/2013WR014147.

Tetzlaff, D., C. Soulsby, S. Waldron, IA Malcolm, PJ Bacon, SM Dunn, A. Lilly, and AF Youngson. 2007. "Conceptualization of Runoff Processes Using a Geographical Information System and Tracers in a Nested Mesoscale Catchment." Hydrological Processes 21 (10): 1289-1307.

UKCP09. 2009. "UK Climate Projections."

Webb, B. W., and D. E. Walling. 1985. "Temporal Variation of River Water Temperatures in a Devon River System." Hydrological Sciences Journal 30 (4): 449-64. doi:10.1080/02626668509491011.

691 Wilkerson, Ethel, John M. Hagan, Darlene Siegel, and Andrew A. Whitman. 2006. "The

692 Effectiveness of Different Buffer Widths for Protecting Headwater Stream

693 Temperature in Maine." Forest Science 52 (3): 221-31. 


\begin{tabular}{|c|c|c|c|c|c|c|}
\hline Catchment & $\begin{array}{l}\text { Area } \\
(\mathrm{km} 2)\end{array}$ & $\begin{array}{l}\text { \% wetland } \\
\text { soils }\end{array}$ & $\begin{array}{l}\text { Mean } \\
\text { Slope } \\
\left({ }^{\circ}\right)\end{array}$ & Aspect $\left({ }^{\circ}\right)$ & $\begin{array}{l}\text { Mean } \\
\text { elevation } \\
\text { (m) }\end{array}$ & $\begin{array}{l}\text { W:D ratio } \\
\text { at point } \\
\text { of } \\
\text { sample }\end{array}$ \\
\hline HW1 & 0.65 & 17.2 & 15 & 146 (NW) & 339 & 1.50 \\
\hline HW2 & 0.43 & 8.4 & 15 & $103(E)$ & 397 & 2.00 \\
\hline HW3 & 0.81 & 22 & 14 & $122(\mathrm{NW})$ & 409 & 0.75 \\
\hline SW4 & 2.03 & 10.3 & 14 & 126 (NW) & 379 & 1.00 \\
\hline SW5 & 2.04 & 17.9 & 14 & $126(\mathrm{NW})$ & 378 & 1.75 \\
\hline SW6 & 2.29 & 18.2 & 13 & 138 (NW) & 371 & 3.00 \\
\hline SW7 & 2.39 & 18.3 & 13 & 141 (NW) & 368 & 1.00 \\
\hline SW8 & 2.44 & 18.6 & 13 & 143 (NW) & 367 & 1.17 \\
\hline SW9 & 2.54 & 19.1 & 13 & 145 (NW) & 364 & 1.17 \\
\hline SW10 & 2.82 & 20.8 & 13 & 150 (NW) & 358 & 0.88 \\
\hline SW11 & 3.16 & 21.5 & 13 & 151 (NW) & 352 & 3.50 \\
\hline $\begin{array}{l}\text { Bruntland } \\
\text { Burn }\end{array}$ & 3.29 & 21.5 & 13 & 151 (NW) & 349 & 1.30 \\
\hline
\end{tabular}

Table 1: Characteristics of the catchment areas above each of the stream water temperature loggers, including the three headwaters (HW1-HW3). 


\begin{tabular}{|c|c|c|c|c|c|c|}
\hline & Mean $\left({ }^{\circ} \mathrm{C}\right)$ & $\begin{array}{l}\text { Minimum } \\
\left({ }^{\circ} \mathrm{C}\right)\end{array}$ & \begin{tabular}{|l|} 
Maximum \\
$\left({ }^{\circ} \mathrm{C}\right)$
\end{tabular} & $\begin{array}{l}\text { Max-Min } \\
\text { Difference } \\
\left({ }^{\circ} \mathrm{C}\right)\end{array}$ & \begin{tabular}{|l|} 
Std. \\
Deviation \\
$\left({ }^{\circ} \mathrm{C}\right)$ \\
\end{tabular} & Degree Days \\
\hline HW1 & 6.55 & -0.03 & 21.07 & 21.1 & 5.45 & 2392 \\
\hline HW2 & 6.45 & 0.06 & 23.70 & 23.64 & 5.33 & 2355 \\
\hline HW3 & 6.31 & 0.04 & 17.53 & 17.49 & 4.71 & 2303 \\
\hline SW4 & 6.41 & 0.06 & 18.19 & 18.13 & 4.90 & 2340 \\
\hline SW5 & 6.41 & 0.03 & 18.30 & 18.27 & 4.92 & 2341 \\
\hline SW6 & 6.44 & 0.07 & 18.24 & 18.17 & 4.89 & 2350 \\
\hline SW7 & 6.40 & 0.05 & 18.15 & 18.1 & 4.85 & 2338 \\
\hline SW8 & 6.42 & 0.06 & 18.09 & 18.03 & 4.81 & 2343 \\
\hline SW9 & 6.41 & 0.04 & 17.99 & 17.95 & 4.75 & 2340 \\
\hline SW10 & 6.02 & -0.55 & 17.73 & 18.28 & 4.90 & 2198 \\
\hline SW11 & 6.32 & -0.31 & 18.23 & 18.54 & 4.87 & 2305 \\
\hline $\begin{array}{l}\text { Deep } \\
\text { groundwater } \\
\text { (GW1) }\end{array}$ & 6.98 & 5.49 & 8.67 & 3.18 & 1.02 & 2666 \\
\hline $\begin{array}{l}\text { Shallow } \\
\text { groundwater } \\
\text { (GW2) }\end{array}$ & 5.50 & 1.36 & 13.32 & 11.97 & 3.39 & 2207 \\
\hline $\begin{array}{l}\text { Shallow } \\
\text { groundwater } \\
\text { (GW3) }\end{array}$ & 5.82 & 1.81 & 12.96 & 11.15 & 3.25 & 2308 \\
\hline $\begin{array}{l}\text { Shallow } \\
\text { groundwater } \\
\text { (GW4) }\end{array}$ & 6.69 & 3.29 & 11.02 & 7.73 & 2.31 & 2440 \\
\hline $\begin{array}{l}\text { Surface } \\
\text { water } \\
\text { (SFW1) }\end{array}$ & 6.31 & 0.28 & 19.53 & 19.25 & 4.90 & 2301 \\
\hline $\begin{array}{l}\text { Surface } \\
\text { water } \\
\text { (SFW2) }\end{array}$ & 6.44 & -0.89 & 19.53 & 20.42 & 5.14 & 2352 \\
\hline $\begin{array}{l}\text { Surface } \\
\text { water } \\
\text { (SFW3) }\end{array}$ & 6.17 & 0.15 & 17.43 & 17.28 & 5.05 & 2132 \\
\hline $\begin{array}{l}\text { Surface } \\
\text { water } \\
\text { (SFW4) }\end{array}$ & 6.43 & -9.11 & 23.78 & 32.89 & 5.69 & 2362 \\
\hline $\begin{array}{l}\text { Air } \\
\text { temperature }\end{array}$ & 5.74 & -13.59 & 22.11 & 35.7 & 6.00 & 1865 \\
\hline
\end{tabular}

Table 2: Descriptive statistics for all stream water (HW1-3 and SW4-11), groundwater (GW14) during the period July 2012 to July 2013 (based on hourly data). The period was chosen to avoid biasing the data by including two summer periods. 


\begin{tabular}{|c|c|c|c|c|c|c|c|c|c|c|c|c|c|}
\hline & & HW1 & HW2 & HW3 & SW4 & SW5 & SW6 & SW7 & sW8 & SW9 & SW10 & sW11 & AT \\
\hline \multirow[t]{4}{*}{ Summer 2012} & Mean & 12.90 & 12.55 & 12.05 & 12.29 & 12.31 & 12.33 & 12.27 & 12.23 & 12.16 & 11.88 & 12.14 & 11.77 \\
\hline & Minimum & 5.53 & 5.66 & 7.10 & 6.74 & 6.70 & 6.76 & 6.81 & 6.73 & 6.59 & 5.79 & 5.65 & -3.31 \\
\hline & Maximum & 21.47 & 21.49 & 17.53 & 18.35 & 18.61 & 18.62 & 18.54 & 18.41 & 18.14 & 17.73 & 18.11 & 22.11 \\
\hline & Std. Deviation & 2.62 & 2.51 & 1.71 & 1.93 & 1.95 & 1.94 & 1.92 & 1.91 & 1.91 & 2.04 & 1.99 & 3.70 \\
\hline \multirow[t]{4}{*}{ Autumn 2012} & Mean & 3.76 & 3.89 & 4.34 & 4.19 & 4.17 & 4.21 & 4.19 & 4.23 & 4.25 & 3.75 & 4.08 & 3.62 \\
\hline & Minimum & -0.02 & 0.10 & 0.08 & 0.09 & 0.06 & 0.09 & 0.07 & 0.08 & 0.07 & -0.55 & -0.26 & -12.10 \\
\hline & Maximum & 11.67 & 12.03 & 9.91 & 10.29 & 10.25 & 10.25 & 10.11 & 10.13 & 10.19 & 10.24 & 10.59 & 15.05 \\
\hline & Std. Deviation & 2.84 & 2.77 & 2.47 & 2.57 & 2.58 & 2.57 & 2.56 & 2.54 & 2.51 & 2.55 & 2.57 & 4.42 \\
\hline \multirow[t]{4}{*}{ Winter 2012/13 } & Mean & 1.30 & 1.33 & 1.51 & 1.49 & 1.48 & 1.53 & 1.53 & 1.59 & 1.65 & 1.14 & 1.46 & 1.24 \\
\hline & Minimum & -0.03 & 0.06 & 0.04 & 0.06 & 0.03 & 0.07 & 0.05 & 0.06 & 0.04 & -0.55 & -0.31 & -13.60 \\
\hline & Maximum & 5.96 & 5.67 & 5.37 & 5.52 & 5.53 & 5.57 & 5.56 & 5.59 & 5.64 & 5.41 & 5.58 & 11.82 \\
\hline & Std. Deviation & 1.37 & 1.27 & 1.24 & 1.27 & 1.28 & 1.27 & 1.27 & 1.27 & 1.27 & 1.33 & 1.33 & 3.85 \\
\hline \multirow[t]{4}{*}{ Spring 2013} & Mean & 8.00 & 7.76 & 7.13 & 7.44 & 7.47 & 7.47 & 7.43 & 7.44 & 7.39 & 7.10 & 7.36 & 6.09 \\
\hline & Minimum & -0.03 & 0.06 & 0.07 & 0.08 & 0.04 & 0.07 & 0.05 & 0.07 & 0.04 & -0.55 & -0.30 & -12.72 \\
\hline & Maximum & 20.80 & 23.70 & 15.97 & 17.30 & 17.58 & 17.04 & 16.54 & 16.67 & 16.95 & 17.73 & 18.23 & 19.39 \\
\hline & Std. Deviation & 4.91 & 5.01 & 4.15 & 4.37 & 4.38 & 4.34 & 4.27 & 4.22 & 4.17 & 4.34 & 4.29 & 5.78 \\
\hline \multirow[t]{4}{*}{ Summer 2013} & Mean & 13.82 & 13.78 & 12.53 & 12.91 & 12.88 & 11.57 & 12.57 & 12.58 & 12.58 & 13.60 & 13.13 & 13.06 \\
\hline & Minimum & 6.15 & 5.36 & 7.64 & 7.38 & 7.21 & 7.09 & 6.67 & 5.72 & 5.75 & 8.04 & 5.23 & 0.26 \\
\hline & Maximum & 23.19 & 25.97 & 17.87 & 19.21 & 19.41 & 19.30 & 19.19 & 19.56 & 19.43 & 20.91 & 21.67 & 26.93 \\
\hline & Std. Deviation & 2.79 & 3.55 & 1.73 & 1.98 & 2.00 & 2.49 & 2.00 & 2.30 & 2.32 & 2.42 & 2.75 & 4.53 \\
\hline
\end{tabular}

Table 3: Descriptive statistics for stream water loggers (HW1-3 and SW4-11) and air temperature (AT) during 5 different seasons $\left({ }^{\circ} \mathrm{C}\right.$, based on hourly data). Seasons defined astronomically. 
a)

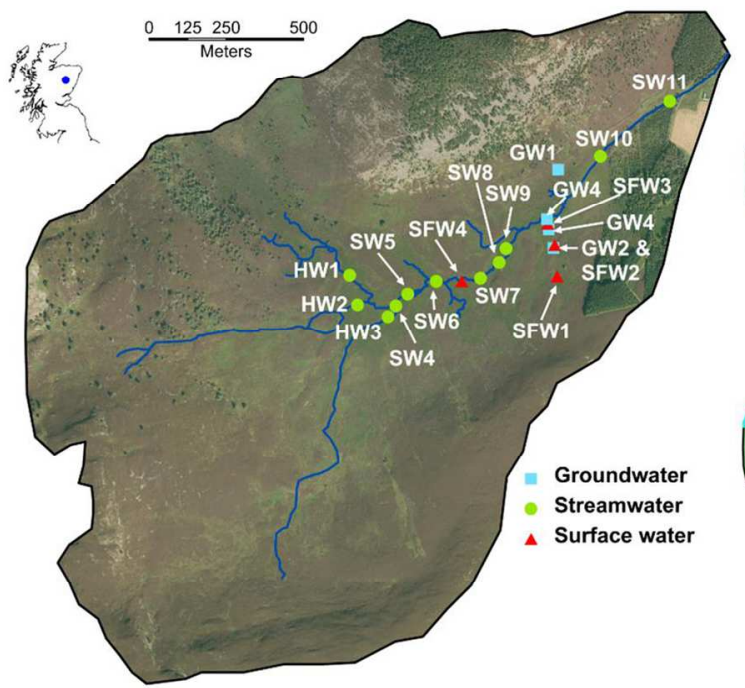

b)

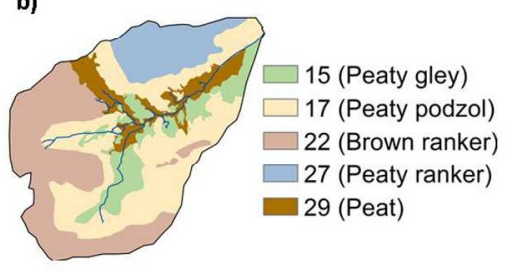

c)

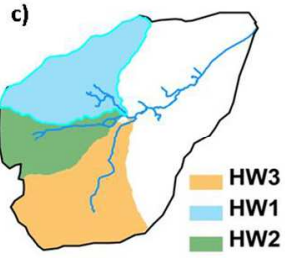

Aerial map of Bruntland Burn valley bottom showing locations of temperature loggers and logger IDs. (HW: Headwater streams; SW: Stream water; GW: Groundwater; SFW: Surface water). The precipitation and dicscharge was measured in the same location as SW11. Map inserts show: a) location of study site within Scotland, b) the location of the headwaters, and c) the soil cover. $244 \times 141 \mathrm{~mm}(150 \times 150 \mathrm{DPI})$ 
a) Mean daily incoming radiation b) Mean daily air temperature, c) precipitation d) discharge and e) daily saturation extent (calculated as percentage of total catchment area) for study period (1st July 12 - 30th June 13) Spring and autumn are shaded in grey. Data from automatic weather station located in the Girnock Burn catchment. $187 \times 148 \mathrm{~mm}(300 \times 300$ DPI) 


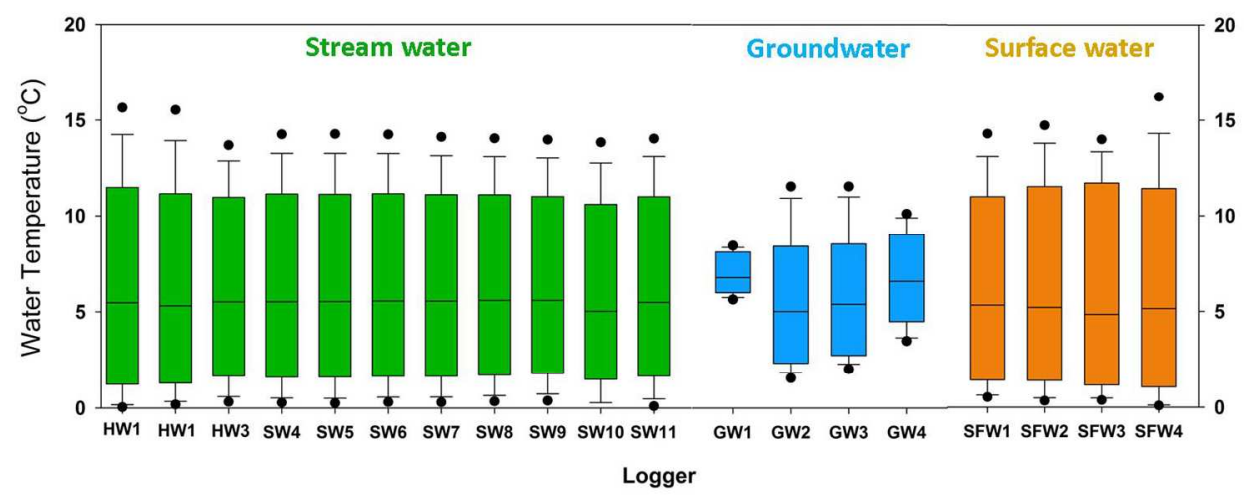

Hourly temperature box plots for each water temperature logger for the period July 2012 to July 2013 . The plot shows: 5th and 95th percentiles (dots); 10th and 90th percentiles (whiskers); 25th and 75th percentiles (box); median (centre line) $281 \times 119 \mathrm{~mm}(150 \times 150 \mathrm{DPI})$ 
Water temperatures for 1st July 12 - 1st July 13. a) Logger SFW4 as an example for an atmospheric driven site; b) GW1 deeper groundwater; c) GW4 Shallow groundwater within riparian zone peats. Loggers were selected to provide examples of deep groundwater with little seasonality, shallow groundwater with more seasonality and greater influence from atmospheric drivers, and the purely atmospherically driven surface water.

$118 \times 87 \mathrm{~mm}(300 \times 300$ DPI $)$ 

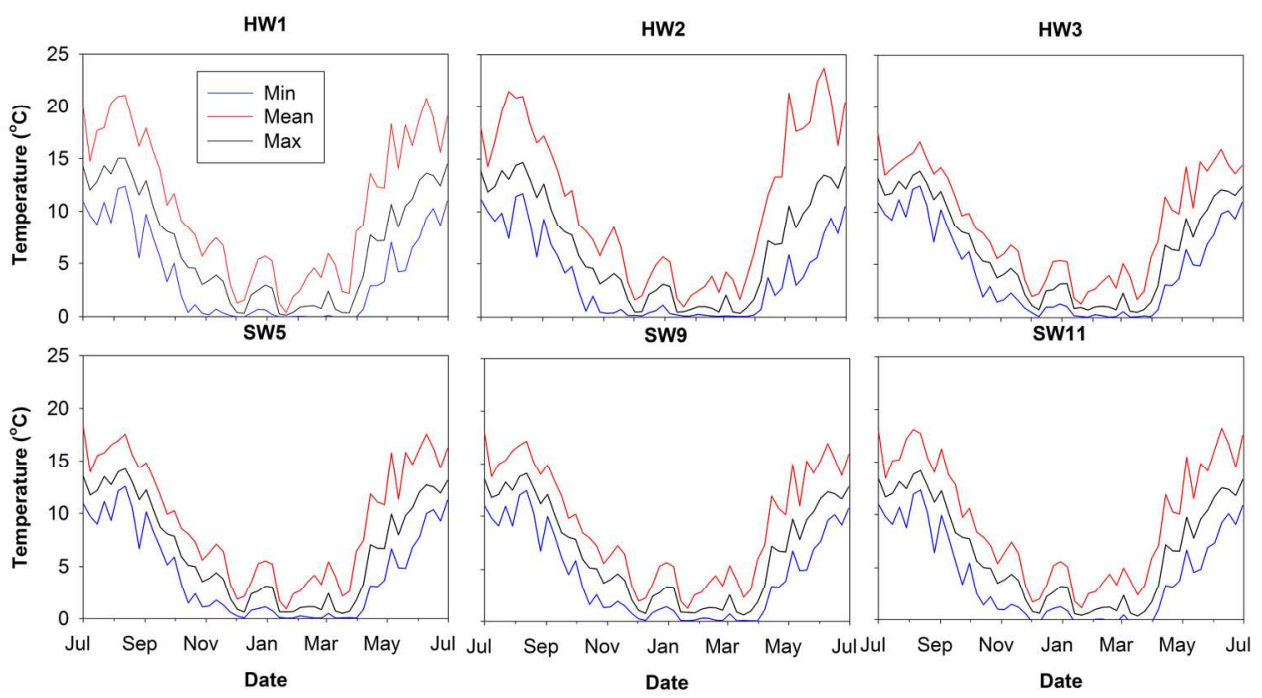

Selected stream water loggers: HW1, HW2, HW3, SW5, SW9 and SW11 clockwise (based on weekly data). Showing Min (blue), max (red) and mean weekly water temperatures (black) for period 1st July 2012 to 30th June 2013

$177 \times 98 \mathrm{~mm}(300 \times 300 \mathrm{DPI})$ 
1

2

3

4

5

6

7

8

9

10

11

12

13

14

15

16

17

18

19

20

21

22

23

24

25

26

27

28

29

30

31

32

33

34

35

36

37

38

39

40

41

42

43

44

45

46

47

48

49

50

51

52

53

54

55

56

57

58

59

60
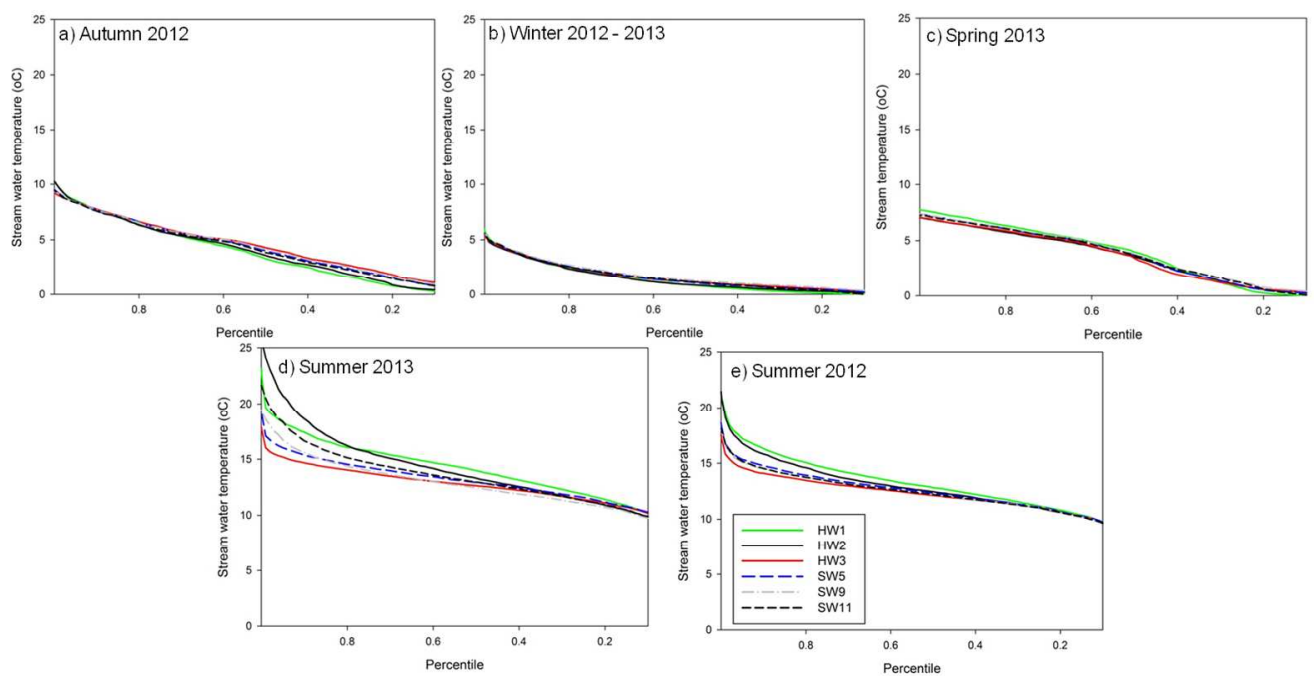

Stream water temperature exceedance curves (based on hourly data) for a) Winter; b) Spring; c) Summer; d) Autumn. Seasons are delineated using astronomical definitions, with each season separated by the two equinoxes and solstices of March 20th, June 21st, September 22nd, December 21st. $276 \times 141 \mathrm{~mm}(150 \times 150 \mathrm{DPI})$ 


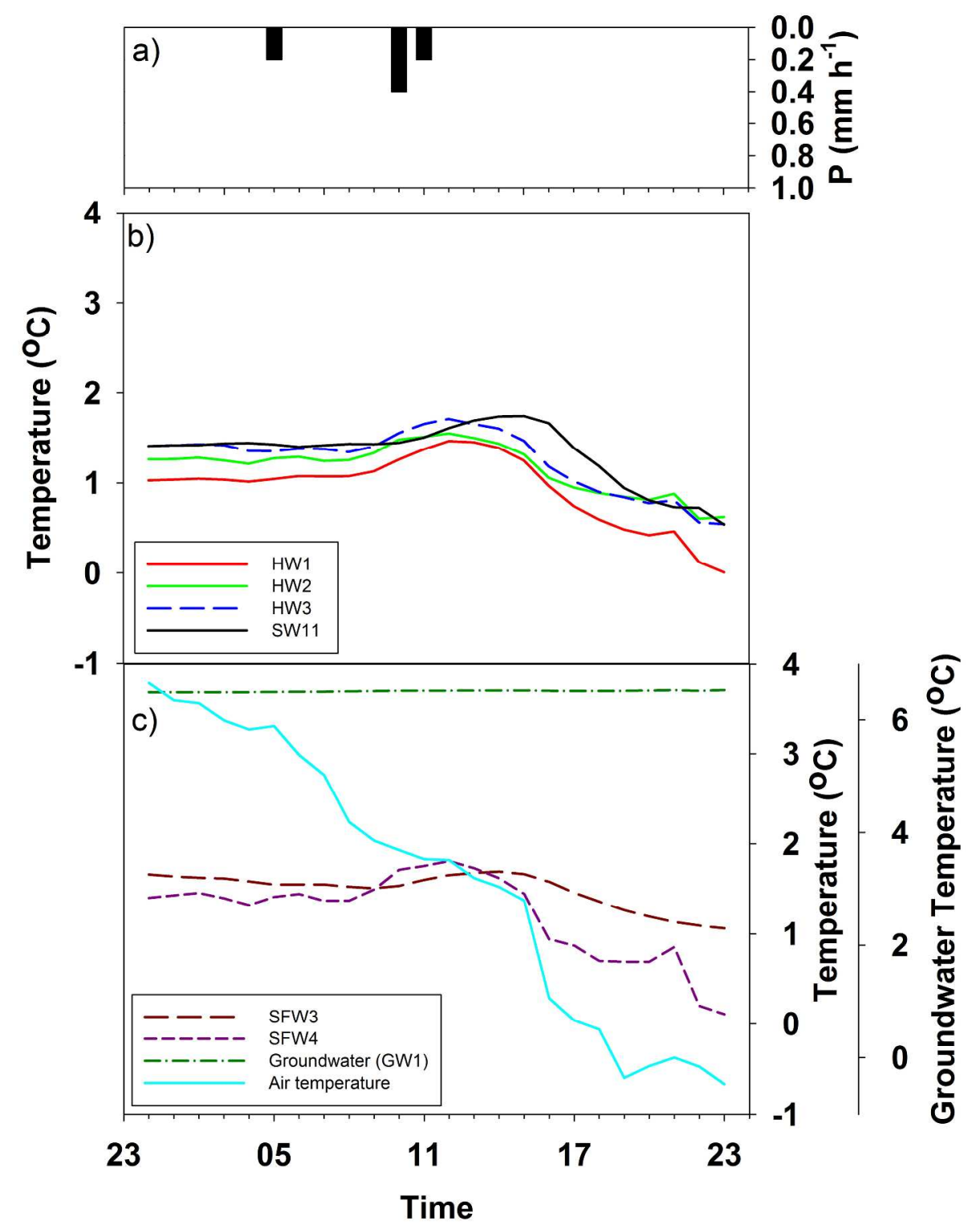

Water temperatures for a $24 \mathrm{hr}$, cold / wet period (1st February 2013); a) precipitation b) Stream water temperatures for each headwater catchment (HW1, HW2, HW3) and the outlet (SW11) and c) Surface water temperatures in riparian zone (SFW1, SFW2 and SFW3) (shown as hourly data). $250 \times 329 \mathrm{~mm}(300 \times 300 \mathrm{DPI})$ 


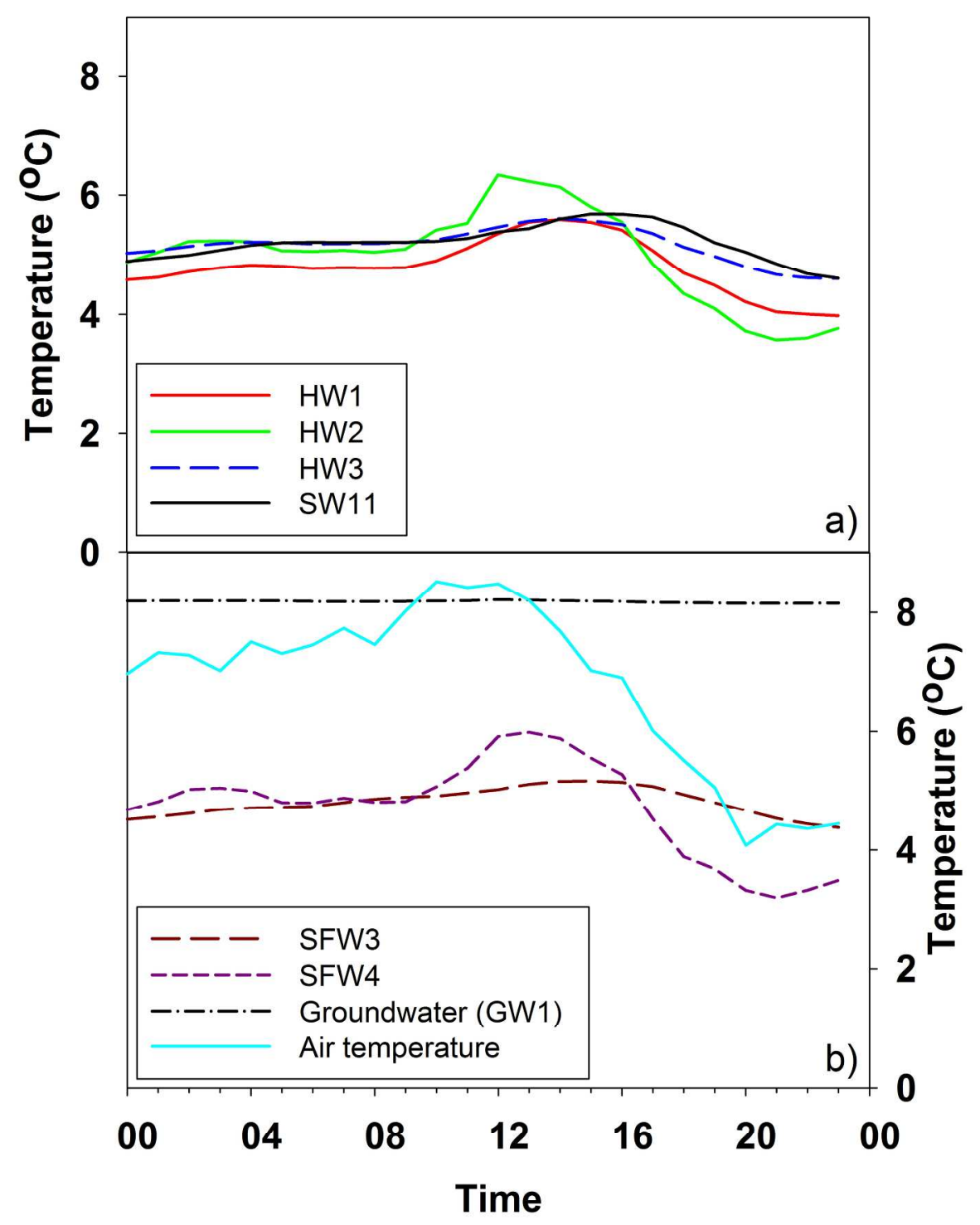

Water temperatures for a $24 \mathrm{hr}$, cold/dry period (9th November 2012) a) Stream water temperatures for each headwater catchment (HW1, HW2, HW3) and the outlet (SW11) and b) Surface water temperatures in riparian zone (SFW1, SFW2 and SFW3) (shown as hourly data). $217 \times 264 \mathrm{~mm}(300 \times 300 \mathrm{DPI})$ 

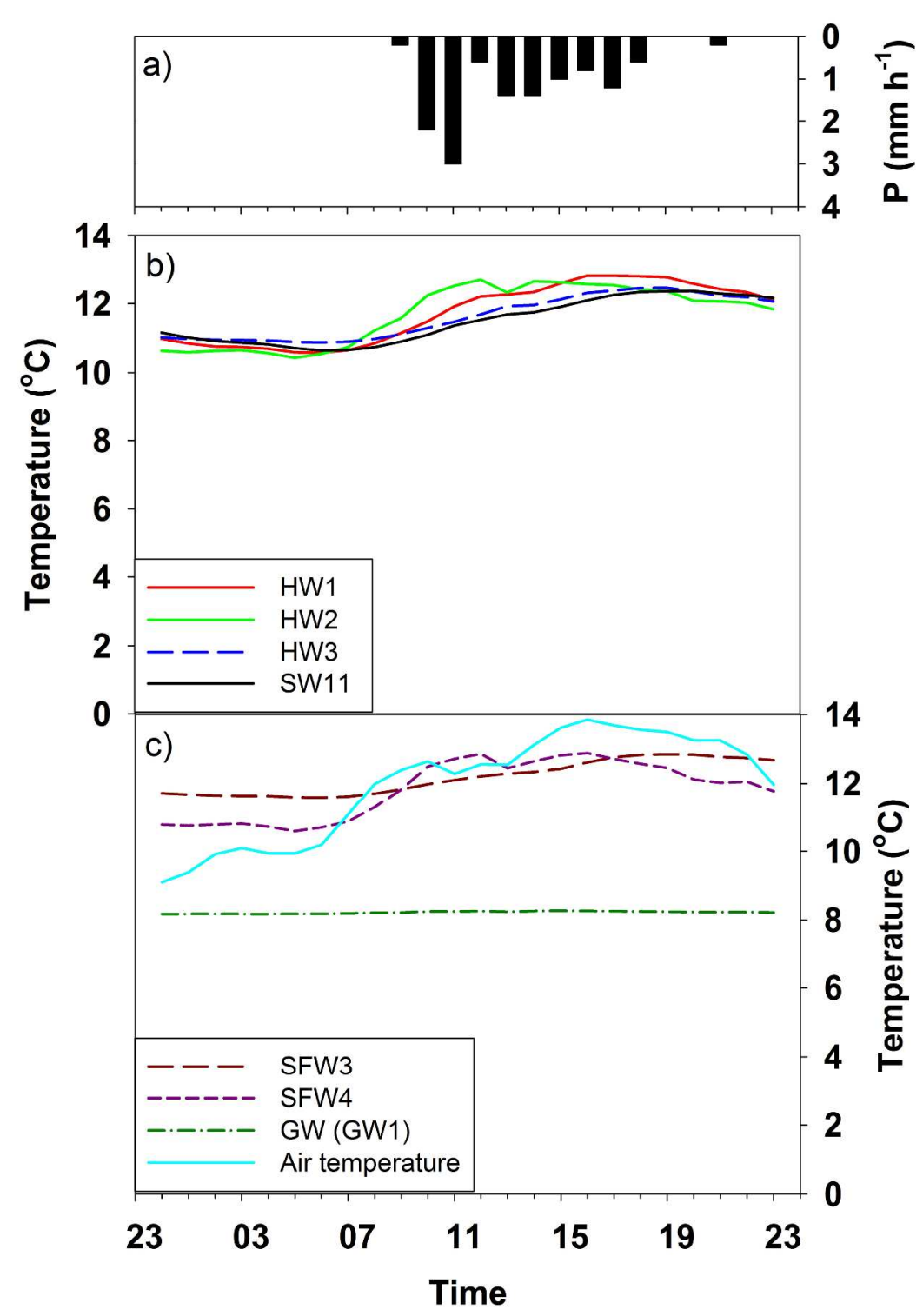

Water temperatures for a $24 \mathrm{hr}$, warm / wet period (27th August 2012): a) precipitation b) Stream water temperatures for each headwater catchment (HW1, HW2, HW3) and the outlet (SW11) and c) Surface water temperatures in riparian zone (SFW3, SFW4, GW1 and air temperature) (shown as hourly data). $255 \times 346 \mathrm{~mm}(300 \times 300 \mathrm{DPI})$ 


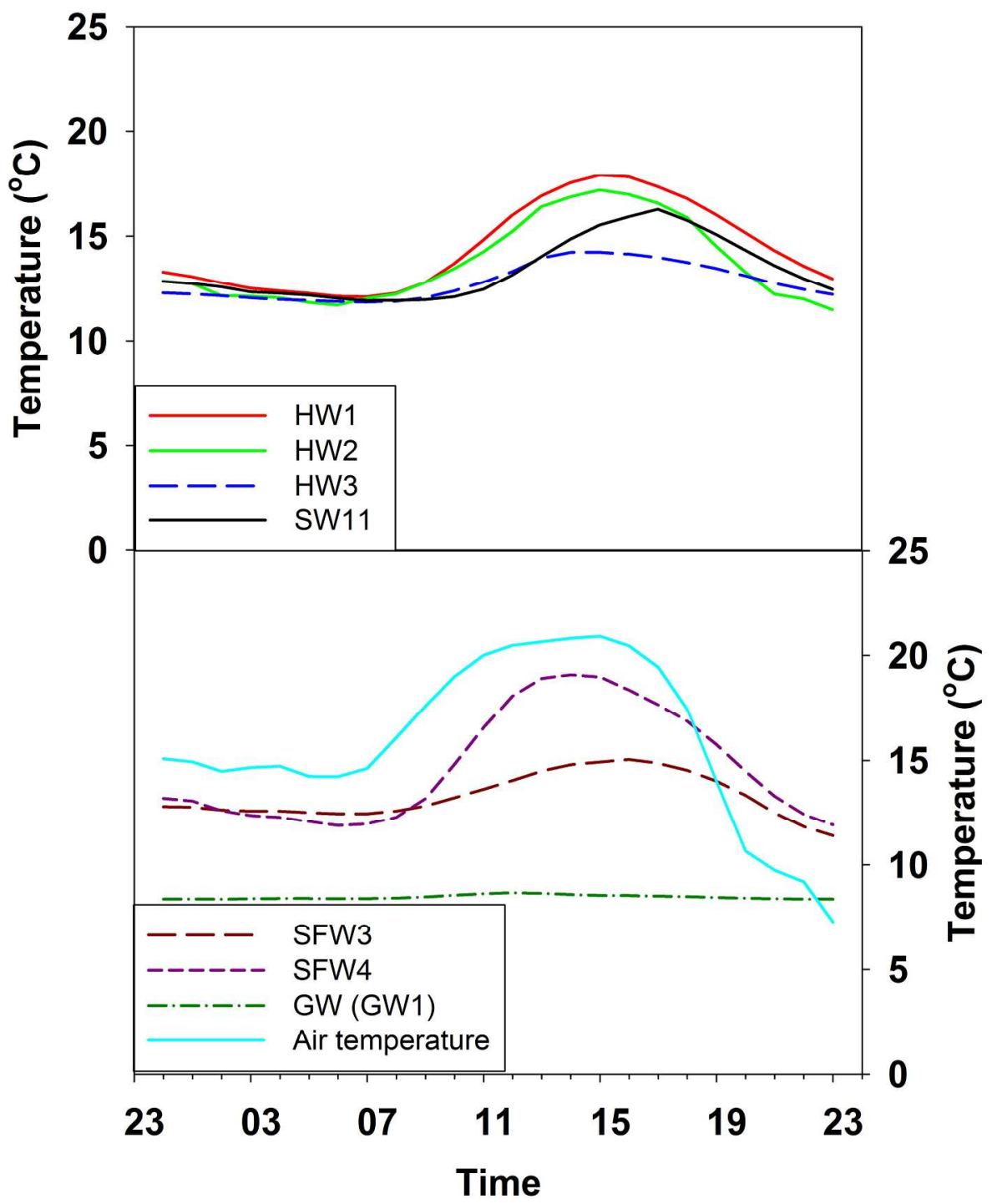

Water temperatures for a $24 \mathrm{hr}$, warm / dry period (8th September 2012) a) Stream water temperatures for each headwater catchment (HW1, HW2, HW3) and the outlet (SW11) and b) Surface water temperatures in riparian zone (SFW3, SFW4, GW1 and air temperature) (shown as hourly data). $221 \times 261 \mathrm{~mm}(300 \times 300 \mathrm{DPI})$ 